\title{
Herbs and Herbals Therapy for Dengue
}

\author{
Bhanumati Mili', Aziz Ahmed², Rahul Singh Kushwaha1, Dr. Kaushal K. Chandrul³ \\ 1Pharmacy Graduate, ${ }^{2}$ Assistant Professor and Researcher, ${ }^{3}$ Faculty of Research and Development \\ 1,2,3Mewar University, Chittorgarh, Rajasthan, India
}

\begin{abstract}
How to cite this paper: Bhanumati Mili | Aziz Ahmed | Rahul Singh Kushwaha | Dr. Kaushal K. Chandrul "Herbs and Herbals Therapy for Dengue" Published in International Journal of Trend in Scientific Research and Development (ijtsrd), ISSN: 2456-

6470, Volume-3 |

Issue-4, June 2019,

pp.103-108, URL:

https://www.ijtsrd.

com/papers/ijtsrd2

3498.pdf

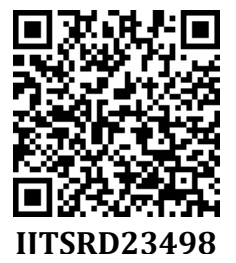

Copyright (C) 2019 by author(s) and International Journal of Trend in Scientific Research and Development Journal. This is an Open Access article distributed under the terms of the Creative Commons

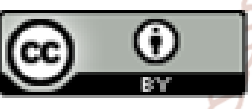
Attribution License (CC BY 4.0) (http://creativecommons.org/licenses/ by $/ 4.0$ )

\section{INTRODUCTION}

Dengue, a viral ailment transmitted by the chomp of the Aedes mosquito, has achieved disturbing extents in the previous couple of years. Today endemic in more than 125 nations, it taints almost 50-270 million individuals consistently, bringing about a sizable number of deaths ${ }^{[1]}$. "Dengue" is gotten from the Swahili expression Ka-dinga pepo, signifying "issue like seizure". The malady has likewise been named "break bone fever" or "dandy fever."[2] An infection related irresistible illness, dengue that spread by mosquitoes, is exceptionally extreme disease [3]. A standout amongst the most deadly difficulties of Dengue fever is hemorrhagic stun which is alluded as Dengue Hemorrhagic Shock ${ }^{[4]}$.Dengue infection (DENV) being an individual from flaviviridea infection family, have envelope and four serotypes; (DENV-1, DENV-2, DENV-3, and DENV-4)[5]. Every one of the four serotypes of dengue infection are transmitted to people by the Aedes aegypti and Aedes albopictus mosquitoes [6]. Albopictus as vector for domatic and peridomasti transmission. Andarboreal Aedes vector for enzootic transmission the flavivirus is family incorporate others vital pathogens has, for example, yellow fever, dengue infections are the causative operators of dengue fever and dengue hemorrhagic fever Its genome is around 11000 bases that codes for three auxiliary proteins (capsid protein C, Membran protein $\mathrm{M}$, encompass protein $\mathrm{E}$ ) and seven nonstructural proteins (NS1, NS2a, NS2b, NS3, NS4b, NS5) it likewise incorporates short non-coding rules on both the 5 and 3 closes ${ }^{[7]}$. Side effects ordinarily begin three to fourteen days after defilement. This may incorporate a high fever, head ach, queasiness, retching, muscle and joint torments, and skin rash. Recuperation takes under two to seven days. ${ }^{[8]}$ Today endemic in more than 125 nations, it contaminates about 50-270 million individuals consistently, bringing about a sizable number of deaths.[9] The most influenced states are Delhi, West Bengal, Kerala, Tamil Nadu, Karnataka, Maharashtra, Rajasthan, Gujarat, and Haryana:[10].

The analysis can be made by IgM ELISA or matched serology amid recuperation or by antigen-location ELISA or RT-PCR amid the intense phase.[6] There are no particular treatment the executives of dengue, other than steady care. ${ }^{[11]} \mathrm{DF}$ was first detailed (WHO) in Sudan, South Kordofan in 1967. Nook 2 was first detailed in Port Sudan in 19863:[12] Transmission of dengue has appeared geographic extension amid the previous decades and is currently endemic in excess of 125 nations. It is evaluated that about 3.6 billion individuals are in danger, while around 50 million to 200 million dengue diseases, 500,000 extreme dengue cases and more than 20,000 dengue related passing's happen every year [13]. The normally happening prescriptions have hostile to viral, mosquitocidal, larvicidal impacts against Aedes aegypti:[14] In dislike, entire resistant framework is animated by these natural drugs, battling against a specific infection, encouraging the body to battle microscopic organisms, infections and illnesses by multiplying the degree of white platelets to turn away signs and symptoms. For case dengue 
is a viral sickness, home grown enemy of viral are specified ${ }^{[15]}$.

\section{IMPORTANT HERBAL MEDICINE FOR CONTROL OF DENGUE VIRUSES}

\section{Papaya Leaves in Dengue Fever}

The utilization of leaves of papaya tree because of their current innate impacts in the treatment of dengue contamination has been generally acknowledged and a matter of incredible worry for the wellbeing of populace. The leaves of papaya (Carica papaya) decoction accounts very powerful for their corrective properties because of the nearness of a few strong constituents like Papain, Ltocopherol, glucosides which are cyanogenic in nature alongside glucosinolates just as flavonoids, cystatin, chymopapain and ascorbic corrosive. Such operators act against free redicals which is connected with decreased development of peroxides of the fat substance, along these lines uncovers its belongings in hindrance of excrescence and tumor developments just as safe modulatory actions ${ }^{[16]}$ and may cause expanded platelet and red platelet counts ${ }^{[17]}$. The leaf juice of papaya improved the strength of patients by expanding the quantity of platelets ${ }^{[18]}$,

\section{Mazu phal:}

Quercus lusitanica or Quercus infectoria (Mazu Phal), contain gallic corrosive and ellagic corrosive. An estimation has been made on the antiviral impacts by the decrease of the cytopathic impact (CPE) of DENV-2 in C6/36 cells alongside the reasoning in infection titre. At centralization of $180 \mu \mathrm{g} / \mathrm{ml}$ unrefined methanol concentrate of Quercus lusitanica stood build up in general frustrate contamination brought about by dengue infection and at last hinder the infection replication by the concentrate of the plant and it demonstrates a portion subordinate inhibition ${ }^{[19] .}$

\section{Echinacea}

Echinacea (additionally called coneflowers) is an outstandingly popular herb, especially for treating the colds and influenza. In the daisy family Asteraceae, Echinacea is a sort of herbaceous blooming plants. The plant has genuine antiviral properties as it spurs cells to yield extra proteins and interferon, made and released by lymphocytes in response to the event of microbes and infections. Echinacea will in like manner deflect and treat dengue, in light of the fact that the colds are viral. Echinacea positively expands Interferon and subsequently persuades the resistant framework overall [20].

\section{Curcuma longa}

Curcuma longa is rhizomatous, herbaceous perpetual plant of ginger family, Zingiberaceae. Its rhizome is utilized as home grown cure. It is additionally utilized in nourishments and in makeup. Ethyl acetic acid derivation concentrate of Curcuma longa rhizomes gives three curcuminoids which show action in hindering topoisomerase I and topoisomerase II, which assume vital job in DNA replication. Out of these three curcuminoides, curcumin III is the best. Turmerone got from unpredictable oil of Curcuma longa give 100\% mosquitocidal action against Aedes aegypti[21].

\section{Piper longum}

Neighborhood name of Piper longum is pipal, pippli. It has a place with family Piperaceae. Three species for example Flute player longum L. $\mathrm{P}$ ribesoides Wall and $\mathrm{P}$. sarmentosum Roxb of this family, as ethanolic separate have been utilized in research. Adequacy of these species is in following request: $\mathrm{P}$. longum $>\mathrm{P}$. sarmentosum Roxb $>\mathrm{P}$ ribesoides Wall. This investigation reason that Pepper plant have action against Aedes aegypti [22].

\section{Anisu Pimpinella}

Animus is normally known as Anisuan, individual from the family Apiaceae. From the whole plant basic oil has been separated having constituents like methylchavicol, cisanethole, $\alpha$-terpineol, linalool, $p$-anisaldehyde and transanethole which has appeared to gangs mutagenic action and incredibly deadly to Aedes aegypti larvae ${ }^{[23]}$.

\section{Kaatu/Dentate clausena}

The plant Clausena dentata has a place with the Rutaceae family. Basic oil acquired by steam refining of leaves of Clausena dentata are fit as repellent in logical inconsistency of Aedes aegypti. The convergences of fundamental oil is legitimately corresponding to the interim term for assurance with the Aedes aegypti nearby the gnawing is denied of aggravation to human skin. Subsequently anti-agents for the control of dengue fever would be substituted by the plant base anti-agents from previously engineered repellent having unfavorable effects ${ }^{[24]}$.

\section{Ipecacuanha}

Because of Hemorrhagic dengue, a homeopathic specialist can utilize home cures as Ipecac root or Ipecacuanha (Carapichea ipecacuanha). Carapichea ipecacuanha is an individual from blooming plants from family Rubiaceae. This is set up from the dried underlying foundations of the plant and quits dying. Patients will imply an emergency clinic in the event that they need intravenous liquids or blood transfusion. To stay away from pandemic ailment as dengue, Ipecacuanha could be prescribed day by day all through the pinnacle periods of dengue. Statutory cures may be accepted toward the start of the pinnacle season and repeating once like clockwork over the span of the pinnacle season [25].

\section{Murraya koenigii}

Nearby name of Murraya koenigii is Kari patah or Kariapat. Family is Rutaceae. It is sweet-smelling deciduous bush of little tree. Entire plant is utilized as home grown cure. The hexane, diethyl ether, dichloromethane and ethyl acetic acid derivation rough concentrates of the entire plant was readied and pupa and grown-up mosquitoes were permitted to develop over yonder. Amid the test hatchlings and grownups were nourished regularly. Because of the trial, larval and pupal misshapenings were watched and there was additionally hindrance of grown-up development. Thus, it causes variations from the norm in grown-up arrangement. In this manner, it very well may be utilized as larvicidal[26].

\section{Barley Grass}

Grain grass has the exceptional capacity to essentially build the body's blood platelet tally by animating the generation of more platelets.[27] You can drink grain tea or eat grain grass legitimately and see a quick increment in platelet check, which is one of the genuine symptoms of dengue fever that can draw out shortcoming and increment the defenselessness of the body to dengue hemorrhagic fever and increasingly genuine inconveniences.

\section{Coriander}

The basic name is coriander organic products. It is acquired from the completely dried ready products of the plant 
Coriandrum sativum Linn. Belonging to family Umblliferae. It is chiefly found in European nation essentially in Russia, Hungery, Holland, In India Andhra Pradesh, and Maharashtra $[28,29]$.The leaves of the coriander can be taken as a tonic to lessen the fevers in dengue.

\section{Neem Leaves}

Neem leaves are ordinarily endorsed for an assortment of sicknesses, and dengue fever is no special case. Soaking neem leaves and after that drinking the consequent blend has been appeared to increment both blood platelet tally and white platelet tally, two of the most perilous reactions of the infection. Legitimately blended neem leaves can improve the resistant framework and return your quality a lot quicker than numerous other home remedies[30].

\section{Andropogon citratum}

Andropogon citratum has a place with the family Poaceae. Its basic name is citronella grass. Dynamic constituents of this plant are fundamental oil and citronella oil. This oil is placed in candles and lamps that can be singed to repulse mosquitoes. Its mosquito repellent characteristics have been confirmed by research, incorporating viability in repulsing Aedes aegypti[31] The nanoemulsions of this plant oil were made and was explored both in-vivo and in-vitro. High weight homogenization to change over bigger emulsion beads $(195-220 \mathrm{~nm})$ to littler size drops (150-160 nm) results in higher discharge rate. Slim movies are acquired from nanoemulsions which have beads of little size. Such movies have greater trustworthiness, consequently, they increment the vaporization of basic oils along these lines delay the action of mosquito repellent ${ }^{[32]}$ Syzygium aromaticum

\section{Basil}

Biting on basil leaves may not sound especially appealing, yet this is known to be an imperative invulnerable boosting strategy and has for quite some time been prescribed in Ayurvedic drug for the treatment of dengue fever ${ }^{[33]}$ Basil fundamental oil likewise has normal insecticidal properties that shield you from mosquitoes, making basil a treatment and a safeguard technique!

\section{Small-egg plant}

Oldenlandia affinis (Small-eggplant) has a place with the Rubiaceae family, contains Cyclotides, ready to restrain dengue viral NS2B-NS3 protease. This hindrance is substrate exact and focused in nature ${ }^{[43]}$

\section{Goldenseal}

Albeit numerous home grown or normal cures aren't straightforwardly affirmed or demonstrated through research, homeopathic doctors have adulated goldenseal for its capacity to clear up the side effects of dengue fever in all respects rapidly and dispense with the infection from the body. [35] Goldenseal not just facilitates fevers, chills, migraines, queasiness, and heaving, yet its regular antiviral limit can basically fix dengue fever in only days.

\section{Giloy}

Giloy, or Guduchi is a mainstream herb that has for some time been utilized in medications. Known as one of the amritas (underlying foundations of everlasting status), the enduring climbing herb is effectively accessible. The paanformed leaf has cancer prevention agent properties that assistance ensure against free extreme harm, further boosting invulnerability. In addition, it diminishes fever and builds blood platelet tally. It is exceedingly antacid and has calming impacts that are known to help your general invulnerability. Giloy is accessible as powder, containers and juice. The most ideal path is to make a mixture utilizing the powder.[36]

\section{Eravatamia coronaria}

Eravatamia coronaria has a place with the family Apocynaceae. Its leaves are utilized as home grown cure. Unrefined benzene and ethyl acetic acid derivation concentrates of the leaves of Eravatamia coronaria are utilized as repellent for Aedes aegypti. The outcomes are gathered by contemplating the anti-agents action at three unique fixations $1.0,2.5$, and $5.0 \mathrm{mg} / \mathrm{cm}$. These fixations were connected on the skin of lower arm of a man and uncovered against female Aedes aegypti. This plant gives assurance against this mosquito with no unfavorably susceptible impact. The mosquito repellent movement is portion/focus subordinate [37].

\section{Black galingale or Chandramul}

Borneol is a concoction constituent of Kaempferia parviflora, an individual from plant family Zingiberaceae. The pieces of stem and leaves of chandramul have been used as opposed to infection. Studies exhibit that few restorative amalgams which show bioactivity in K. parviflora have capacity to straightforwardly make inadequate the serotype of dengue infection; DENV2. A portion subordinate movement has been appeared some bioactive mixes in K parviflora[38]. The plant separate is additionally successfully utilized as a mosquito repellant ${ }^{[39]}$.

\section{Fenugreek}

Leaves of the plant are referred to diminish temperature just as fills in as a quieting operator in decreasing torment and helping in legitimate rest and rest ${ }^{[40]}$.

\section{Kaempferia parviflora}

Neighborhood name of the plant Kaempferia parviflora is chandramul. Substance constituent is borneol. It has a place with the Zingiberaceae family. Leaves and stem are utilized as home grown cure against infection. Four serotypes for dengue have been perceived for example Lair 1, DEN 2, DEN 3 , and DEN 4. Late investigations demonstrate that DEN 2 particles are straightforwardly inactivated by some bioactive compound in K. parviflora. The plant remove action is portion dependent ${ }^{[41]}$.

\section{Peacock blossom}

Fabaceae having a part known as Caesalpinia pulcherrima which is a types of blossoming plant, the concentrate of this plant leaves alongside rough benzene and ethyl acetic acid derivation are utilized as repungent for Aedes aegypti[42].

\section{Orange Juice}

The rich blend of cell reinforcements and nutrients found in squeezed orange make it perfect for treating the auxiliary indications of dengue fever and taking out the infection. Squeezed orange advances antibodies of the resistant framework, increment pee and the arrival of poisons, and invigorates cell fix because of nutrient C's vital job in the making of collagen.[43] 


\section{Fruits wealthy in nutrient $C$}

Organic products wealthy in nutrient $\mathrm{C}$ like Embellica officinalis (amla) are prescribed for dengue treatment as nutrient $\mathrm{C}$ bolsters improved iron retention and it is additionally a chelator. Episode with dengue can be countered by nutrient $\mathrm{C}$ at $500 \mathrm{mg}$ for children. There are additionally stories that enhancements of chlorophyll were used in opposition to dengue fever. Chlorophyll involves magnesium that also is a chelator ${ }^{[44]}$

\section{Pinwheel jasmine/crepe jasmine}

Ervatamia coronaria leaves (Pinwheel Jasmine/Crepe Jasmine) having a place with family Apocynaceae are utilized as naturall solution for shield the mosquito bite ${ }^{[45]}$.

\section{Chinese Ginger}

Chinese ginger is the neighborhood assignment of Boesenbergia rotunda. NS2B is a film related protein used to grapple and control the replication compound amid viral life cycle. NS2B-NS3 is a serine protease vital for the handling of polyprotein basic for infection replication, impact of gatherings of falvanones in addition to their chalcones against protease of DENV-2 [46-49].

\section{Irish greenery/carrageen greenery}

Chondrus crispus (Irish greenery, Red kelp) having a place with the Family Gigartinaceae is a mechanical wellspring of carrageenan. Carrageenans have a place with class of regular polysaccharides. Red ocean growth are known to be carrageenophytes, delivering kappa, particle and lambdacarrageenans which have been accounted for with successful antiviral effect[50].

\section{Japanese orchid (Gastrodia elata)}

Gastrodia elata has an inhibitory potential and has perceived the antiviral potential against dengue infection serotype 2 in vitro by methods for BHK cell line (Baby Hamster kidney fibroblast cells). The inadequacy of WSS45 in the wake of entering the vulnerable cell capably recommends that it is an infection section inhibitor ${ }^{[51]}$.

\section{Baikal skullcap (Scutellaria baicalensis)}

A remarkable impact against every one of the four serotypes of dengue infection in-vitro has been uncovered in the watery and cold concentrate of S.baicalnesis roots. It has likewise been discovered that the concentrate especially intended to impact at a few unmistakable periods of contamination brought about by dengue infection just as restrain infection duplication. The solid straight impacts of S.baicalensis extricate against the infection which go about as a pivotal point for hostile to dengue treatment improvement since this may likewise demolish the infection existing in patient's circulatory system. The capacity of plant remove S.baicalensis by and by having hostile to viral impacts and the event of a flavonoid, Baicalein which forces inhibitory impacts against the dengue infection replication attainably appeared to have fixings which are sufficiently satisfactory to indicate common subterranean insect viral activity[52].

\section{CONCLUSION}

Dengue infection is causes the Dengue fever in human by the mosquito chomp .Many individuals passed on by dengue fever. At that point the issue is created how to control dengue fever. There are many home solutions for control of dengue fever which can be effectively gotten and shoddy and furthermore free from reactions, for example, utilization of Ipecacuanha, basil, Echinacea, papaya, Astragalus, Neem, grape, kari path, peacock flower, giloy and orange juices etc. As home cures are effectively accessible, reasonable, important and exceedingly viable, it is prescribed to dengue patients to utilize these home cures.

\section{ACKNOWLEDGEMENT}

In the course of this article, I have received help from a number of people. First of all I would like to thanks them all.

I wish to express my sincere gratitude to our Mr. Aziz Ahmed for providing me an opportunity to do my article work entitled "HERBS AND HERBAL THERAPY FOR DENG"E", I sincerely thank Mr. Aziz Ahmed for their guidance and encouragement during this article and I am grateful to our department for giving me an opportunity to do this article.

\section{REFERENCE}

[1] Ferreira GL. Global dengue epidemiology trends. Rev Inst Med Trop Sao Paulo 2012; 54 Suppl 18:S5-6.

[2] K3. imura R, Hotta S. Studies on dengue fever (IV) on inoculation of dengue virus into mice. Nippon Igaku $1944 ; 3379: 629-33.3$

[3] Safila Naveed et al.: Awareness of Dengue Virus in Professionals and General Public, International Journal of Clinical Medicine, Research. Vol. 1, No. 4, 2014, pp. 121-124.

[4] Viroj Wiwanitkit, Dengue Fever: Diagnosis and Treatment, Expert Rev Anti Infect Ther. 2010;8(7):841845.

[5] Gubler DJ: Epidemic dengue/dengue hemorrhagic fever as a public health, social and economic problem in the 21st century. Trends Microbiol. 2002, 10:100-103.

[6] 7 Wright, P. F.; Durbin, A. P.; Whitehead, S. S.; Ikizler, M. R.; Henderson, S.; Blaney, J. E.; Thumar, B.; Ankrah, S.; Rock, M. T; McKinney, B. A.; et al. Phase 1 trial of the dengue virus type 4 vaccine candidate $\operatorname{rDEN} 4\{$ Delta\} $30-4995$ in healthy adult volunteers. Am. J. Trop. Med. Hyg. 2009, 81, 834-841.

[7] Comprehensive Guidelines for prevention and control of Dengue and Dengue Hemorrhages' fever. WHO library Caaloguuing in publication data.

[8] Sophie A, et al. Enzyme-linked immunosorbent assay specific to dengue virus type 1 non-structural protein ns1 reveals circulation of the antigen in the blood during the acute phase of disease in patients experiencing primary or secondary infections. J Clin Microbiol. 2002; 40:376-381.

[9] Ferreira GL. Global dengue epidemiology trends. Rev Inst Med Trop Sao Paulo 2012;54 Suppl 18:S5-6.

[10] National Vector Borne Disease Control Programme. Annual Report 2014-15. Ministry of Health and Family Welfare. Government of India. http://nvbdcp.gov.in/doc/annual-report-nvbdcp2014-15.pdf Accessed on 1 July 2016.

[11] Kelly JD, Shandera WX. Viral and Rickettsial Infections. In: Papadakis MA, McPhee SJ, Rabow MW, editors. 2016: Current Medical Diagnosis and Treatment. 55th ed. McGraw-Hill Education; New York: 2016.pp. 1342416. 
International Journal of Trend in Scientific Research and Development (IJTSRD) @ www.ijtsrd.com eISSN: 2456-6470

[12] Hyams KC, Oldfield EC, Scott RM, Bourgeois AL, Gardiner H, Pazzaglia G, Moussa M Saleh AS, Dawi OE, Daniell FD. Evaluation of febrile patients in PortSudan, Sudan: isolation of dengue virus. Am J Trap Med Hyg 1986; 35: 860-865.

[13] Natasha Evelyn Anne Murray, Mikkel B Quam, Annelies Wilder-Smith. Epidemiology of dengue: past, present and future prospects. Clin Epidemiol. 2013; 5: 299309. Published online 2013 August 20. doi: 10.2147/CLEP.S34440PMCID: PMC3753061.

[14] Saleem et al, PREVENTION AND TREATMENT OF DENGUE WITH NATURAL DRUGS, Pak. J. Pharm. 24(1 \& 2) $51-53,2011$

[15] Klawikkan N, Nukoolkarn V, Jirakanjanakir N, Yoksan S, Wiwat C, Thirapanmethee K. Effect of Thai medicinal plant extracts against Dengue virus in vitro. MU J Pharm. 2011; 38(1-2): 13-18.

[16] Otsuki N, Dang N H, Kumagai E, Kondo A, Iwata S, Morimoto C. Aqueous extract of Carica papaya leaves exhibits anti-tumor activity and immunomodulatory effects. J Ethno pharmacology. 2010;127:760-7.

[17] Dharmarathna SL, Wickramasinghe S, Waduge RN, Rajapakse RP, Kularatne SA. Does Carica papaya leaf extract increase the platelet count? An experimental study in a murine model. Asian Pac J Trop Biomed. 2013;3:720-4.

[18] Kala CP (2012) Leaf Juice of Carica papaya L.: A Remedy of Dengue Fever. Med Aromat Plants 1:109. doi:10.4172/21670412.1000109

[19] Noorsaadah R, Hadinur, Sylvia Muliawan, Nurshamimi or Rashid, Mudiana Muhamad and Rohana Y (2006). Studies on quercus iusitanica extracts on DENV-2 Replication. Drug Bulletin, 30(1): 260-269.

[20] Tang LIC, Ling APK, Koh RY, Chye SM, Voon KGL. Screening of anti-dengue activity in methanolic extracts of medicinal plants. BMC Complement Altern Med. 2012; 12: 3.

[21] Roth, G. N., Chandra, A. and Nair, M. G. (1998) Novel bioactivities of Curcuma longa constituents. Journal of Natural Products. 61(4), 542-545.

[22] Chaithong, U., Choochote, W., Kamsuk, K., Jitpakdi, A., Tippawangkosol, P., Chaiyasit, D., Champakaew, D., Tuetun, B. and Pitasawat, B. (2006). Larvicidal effect of pepper plants on Aedes aegypti. Journal of Vector Ecology. 31(1), 138-144.

[23] Veena P, Tripathi AK, Aggarwal KK and Khanuja SPS (2005). Insecticidal, repellent and ovipositiondeterrent activity of selected essential oils against Anopheles stephensi, Aedes aegypti and Culex quinquefasciatus. Bioresource Tech., 96(16): 17491757.

[24] Rajkumar S and Jebanesan A (2010). Prevention of Dengue fever through plant based mosquito repellent Clausena dentata (Willd.) M. Roem (Family: Rutaceae) essential oil against Aedes aegypti L.(Diptera: Culicidae) mosquito, Eur. Rev. Medi. Pharmacol. Sci., 14: 231-234.
[25] Qi RF, Zhang L, Chi CW. Biological characteristics of dengue virus and potential targets for drug design. Acta Biochim Biophys Sin. 2008; 40(2): 91-101.

[26] Arivoli and Tennyson, S. (2011). Studies on the mosquitocidal activity of murraya koenigii (L.) Spreng (Rutaceae) leaf extracts against Aedes Aegypti Anopheles stephensi and Culex quinquefasciatus $S$. Asian journal of Experimental Bioogical Sciences. 2(4), 721-730.

[27] http://www.agriculturejournals.cz/publicFiles/00089. pdf.

[28] C K Kokate, A P Purohit, S P Gokhale. Pharmacognosy 26th Edition published by Nirali Prakashan. 348, 581, 594.

[29] Mohammad Ali. Textbook of pharmacognosy 2nd edition published by CBS publishers and distributors. $380,381,325$.

[30] http://www.ingentaconnect.com/content/ben/cmcaca /2005/00000005/00000002/art00006

[31] Onanong, N., Usawadee, S., Napaporn, U., Satit, P., Apinan S. and Uracha, R. (2009). In vitro characterization and mosquito (Aedes aegypti) repellent activity of essential-oils-loaded nanoemulsions. AAPS Pharmaceutical Science and Technology. 10(4), 1234-1242.

[32] Ibrahim, J. and Zaridah, Z. (1998). Development of environment-friendly insect Repellents from the Leaf oils of selected Malaysian plants. ASEAN Review of Biodiversity and Environmental Conservation (ARBEC). Article VI, Page 1.

[33] http://www.tm.mahidol.ac.th/seameo/2011-42-5/0652328.pdf?origin=publication_detail

[34] 7 Gao Y, Cui T and Lam Y (2010). Synthesis and disulfide bond connectivity-activity studies of a kalata B1inspired cyclopeptide against dengue NS2BNS3protease. Bioorganic Medicin. Chem., 18(3): 13311336.

[35] http://www.seminar.schoolofnaturalhealing.com/sites /seminar.schoolofnaturalhealing.com/files/Golden $\% 2$ 0Seal\%20-\%20Trina\%20Cordingley.pdf.

[36] https//www.ndtv.com/food/dengue-3-herbs-you-canconsume-to-prevent-dengue-fever-1936969

[37] Govindarajan, M., Mathivanan, T., Elumalai,K., Krishnappa, K. and Anandan. A. (2009). Mosquito larvicidal, ovicidal, and repellent properties of botanical extracts against Anopheles stephensi, Aedes aegypti, and Culex quinquefasciatus. Parasitology Research. 109 (2), 353-67

[38] Hafidh RR, Abdulamir AS, Jahanshiri F, Abas F. Abu Bakar and Sekawi Z (2009). Asia is the mine of natural antiviral products for public health. Open Compl. Med. J., 1: 58-68.

[39] Kanjanapothi D (2004). Toxicity of crude rhizome extract of Kaempferia galanga L. (Proh Hom). J. Ethnopharmacol., 90(2-3): 359-365.

[40] Organic Facts, Home Remedies for Dengue Fever, 2015 Organic Information Services Pvt Ltd. 
International Journal of Trend in Scientific Research and Development (IJTSRD) @ www.ijtsrd.com eISSN: 2456-6470

[41] Hafidh, R. R., Abdulamir, A. S., Jahanshiri, F., Abas, F., Abu Bakar, Sekawi, Z. (2009). Asia is the Mine of Natural Antiviral Products for Public Health. The Open Complementary Medicine Journal.1, 58-68.

[42] Govindarajan M, Mathivanan T, Elumalai K, Krishnappa K and Anandan A (2009). Mosquito iarvicidal, ovicidal and repellent properties of botanical extracts against Anopheles stephensi, Aedes aegypti and Culex quinquefasciatus. Parasitology Research, 109(2): 353367

[43] .http://onlinelibrarywiley.com/doi/10.1525/maq.199 1.5.3.02a00050/abstract

[44] Halim SZ, Abdullah NR, Afzan Z, Abdul-Rashid BA, Ja oieh a eeu Carica papaya leaf extract in Sprague Dawley no J Med Plants Res. 2011; 5(10): 18671872.

[45] Govindarajan M, Mathivanan T, Elumalai K, Krishnappa K and Anandan A (2009). Mosquito iarvicidal, ovicidal and repellent properties of botanical extracts against Anopheles stephensi, Aedes aegypti and Culex quinquefasciatus. Parasitology Research, 109(2): 353367.

[46] Bollati M, Alvarez K, Assenberg R, Baronti C, Canard B, Cook S, Coutard B, Decroly E, de Lamballerie X, Gould EA, Grard G, Grimes JM, Hilgenfeld R, Jansson AM, Malet H, Mancini EJ, Mastrangelo E, Mattevi A, Milani M, Moureau G, Neyts J, Owens RJ, Ren J, Selisko B, Speroni S, Steuber H, Stuart DI, Unge T and Bolognesi M (2010).
Structure and functionality in flavivirus NS-proteins: Perspectives for drug design. Antiviral Res., 87(2): 125148.

[47] Keller TH, Chen YL, Knox JE, Lim SP, Ma NL, Patel SJ, Sampath A, Wang QY and Yin Z (2006). Vasudevan SG. Finding new medicines for flaviviral targets. Novartis Foundation Symposium, 277: 102-114.

[48] Kiat TS, Pippen R, Yusof R, Ibrahim H, Khalid N and Rahman NA (2006). Inhibitory activity of cyclohexenyl.

[49] chalcone derivatives and flavonoids of finger root, Boesenbergia rotunda (L.), towards dengue- 2 virus NS3 protease. Bioorg. Medic. Chem. Let., 16(12):33373340.

[50] Talarico LB, Zibetti RGM, Faria PCS, Scolaro LA, Duarte MER and Noseda MD et al. (2004). Anti-herpes simplex virus activity of sulfated galactans from the red seaweeds Gymnogongrus griffithsiae and Cryptonemia crenulata. Inter. J. Biol. Macromolecules, 34: 63-71

[51] Tong XK, Qiu H, Zhang X, Shi LP, Wang GF, Ji FH, Ding HY, Tang W, Ding K and Zuo JP (2010). WSS45, a sulfated alpha-Dglucan, strongly interferes with Dengue 2 virus infection in vitro. Acta. Pharmalogica. Sinica., 31(5): 585-592.

[52] Zandi et al. Extract of Scutellaria baicalensis inhibits dengue virus replication BMC Complementary and Alternative $\quad$ Medicine 2013, 13:91 http://www.biomed central. com/1472-6882/13/9 